\title{
Purification of ${ }^{238} \mathrm{Pu}$ Oxide using the Pu Oxalate Process
}

\author{
D. A. Mew, O. H. Krikorian, K. E. Dodson, J. A. Schmitz
}

\section{November 28, 2001}

U.S. Department of Energy

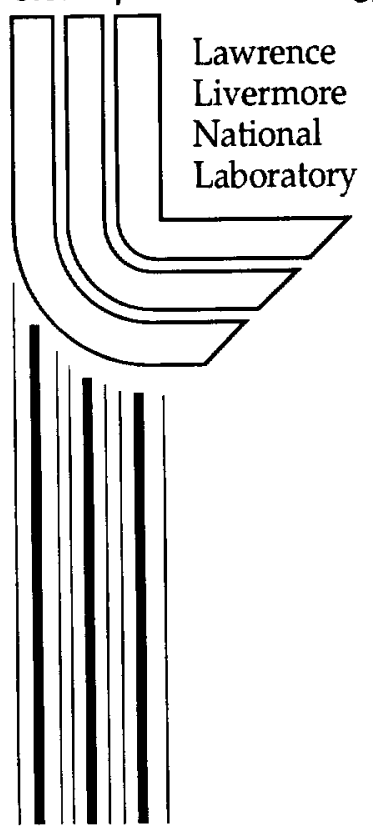




\section{DISCLAIMER}

This document was prepared as an account of work sponsored by an agency of the United States Government. Neither the United States Government nor the University of California nor any of their employees, makes any warranty, express or implied, or assumes any legal liability or responsibility for the accuracy, completeness, or usefulness of any information, apparatus, product, or process disclosed, or represents that its use would not infringe privately owned rights. Reference herein to any specific commercial product, process, or service by trade name, trademark, manufacturer, or otherwise, does not necessarily constitute or imply its endorsement, recommendation, or favoring by the United States Government or the University of California. The views and opinions of authors expressed herein do not necessarily state or reflect those of the United States Government or the University of California, and shall not be used for advertising or product endorsement purposes.

This work was performed under the auspices of the U.S. Department of Energy by the University of California, Lawrence Livermore National Laboratory under Contract No. W-7405-Eng-48.

This report has been reproduced directly from the best available copy.

Available electronically at http://www.doc.gov/bridge

Available for a processing fee to U.S. Department of Energy

And its contractors in paper from

U.S. Department of Energy

Office of Scientific and Technical Information

P.O. Box 62

Oak Ridge, TN 37831-0062

Telephone: (865) 576-8401

Facsimile: (865) 576-5728

E-mail: reports@adonis.osti.gov

Available for the sale to the public from

U.S. Department of Commerce

National Technical Information Service

5285 Port Royal Road

Springfield, VA 22161

Telephone: (800) 553-6847

Facsimile: (703) 605-6900

E-mail: orders@ntis.fedworld.gov

Online ordering: http://www.ntis.gov/ordering.htm

\section{OR}

Lawrence Livermore National Laboratory

Technical Information Department's Digital Library

http://www.llnl.gov/tid/Library.html 


\title{
Purification of ${ }^{238} \mathrm{Pu}$ Oxide using the Pu Oxalate Process
}

\author{
Daniel A. Mew, Oscar H. Krikorian, Karen E. Dodson, and Joseph A. Schmitz
}

\section{Abstract}

The $\mathrm{Pu}$ oxalate process is used to remove ${ }^{234} \mathrm{U}$ from aged ${ }^{238} \mathrm{Pu}$-enriched $\mathrm{PuO}_{2}\left({ }^{234} \mathrm{U}\right.$ grows into the $\mathrm{PuO}_{2}$ material with time from $\alpha$-decay of $\left.{ }^{238} \mathrm{Pu}\right)$. The $\mathrm{Pu}$ oxalate process was first used on a mixture of weapons grade $\mathrm{PuO}_{2}$ with $\mathrm{UO}_{2}$ to work out the processing parameters. It was then applied to aged ${ }^{238} \mathrm{Pu}$ enriched $\mathrm{PuO}_{2}\left({ }^{238} \mathrm{PuO}_{2}\right)$. The ${ }^{234} \mathrm{U}$ content of the ${ }^{238} \mathrm{PuO}_{2}$ was reduced from $13.2 \mathrm{wt} \%$ to $0.0254 \mathrm{wt} \%$, and the Pu recovery yield was $78.5 \%$. The process is complex and is complicated by radiolysis problems when working with ${ }^{238} \mathrm{Pu}$. Details of the experiments are described.

\section{Introduction}

There is a need to purify ${ }^{238} \mathrm{PuO}_{2}$ materials of non-Pu elements so that the ${ }^{238} \mathrm{Pu}$ can be used in forming ${ }^{238} \mathrm{Pu}$-enriched Pu alloys at Lawrence Livermore National Laboratory (LLNL). The primary impurity element in the available LLNL ${ }^{238} \mathrm{PuO}_{2}$ materials is about $13 \mathrm{wt} \%{ }^{234} \mathrm{U}$, which has grown in with time by the alpha decay of ${ }^{238} \mathrm{Pu}$. The plutonium (IV) oxalate process ${ }^{1-4}$ has been described as a purification method that gives high decontamination factors for removal of $\mathrm{Al}, \mathrm{Cr}, \mathrm{Fe}, \mathrm{Ni}$, and $\mathrm{U}$. The decontamination factor for $\mathrm{U}$ is reported to be 60 , i.e.; the process reduces the $U$ content by a factor of 60 . This report describes our initial work in applying the oxalate process to remove ${ }^{234} \mathrm{U}$ from ${ }^{238} \mathrm{PuO}_{2}$ materials.

\section{Process Description}

The Pu oxalate process is carried out in six process steps as depicted in Fig. 1. The literature ${ }^{1-4}$ does not give a specific formulation for carrying out these process steps, but only some broad guidelines. The first step is to dissolve the $\mathrm{PuO}_{2}$. This can be carried out by using concentrated nitric acid to which is added a small amount of hydroflouric acid as a catalyst. This dissolution is a slow process and heating and stirring the solution will speed it up. When dissolution is complete the next step is to dilute the acid down with water. The dilution needs to be sufficient so that in the succeeding step (the oxalate precipitation step) the nitric acid concentration will end up in the range of 1.5 to $4.5 \mathrm{~N}$. Therefore, we estimate that the dilution at this point needs to reduce the $\mathrm{HNO}_{3}$ concentration to within the range of $4-7 \mathrm{~N}$.

The step following dilution is the oxalate precipitation step and two procedures are described ${ }^{1}$. In the first procedure, hydrogen peroxide (sufficient to convert $\mathrm{Pu}^{+3}$ to the $\mathrm{Pu}^{+4}$ state) is added to the solution from the dilution step and the solution is heated to $35-50{ }^{\circ} \mathrm{C}$ until the blue color of the solution 


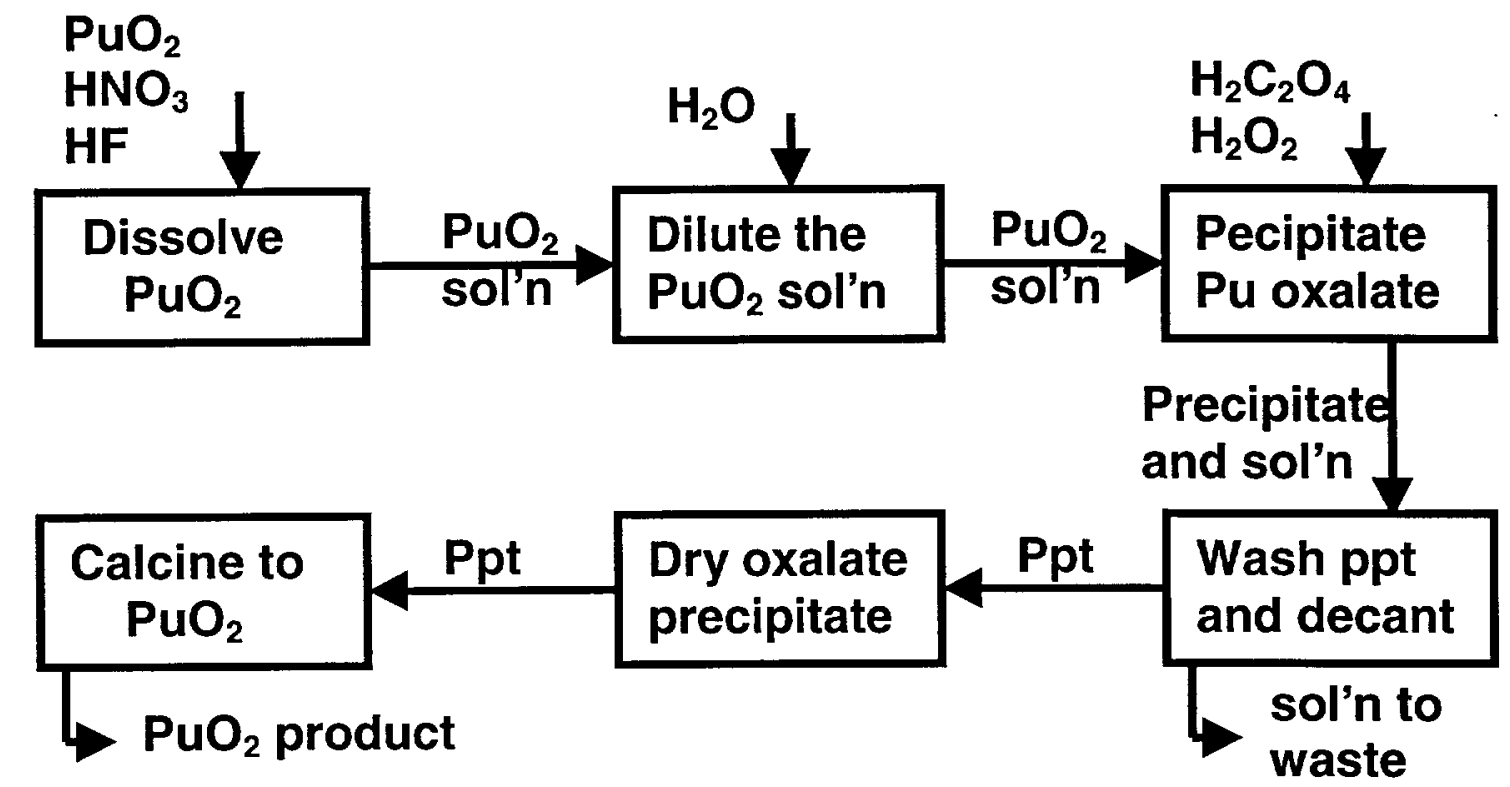

Figure 1. Process steps used for purification of $\mathrm{PuO}_{2}$ by the plutonium (IV) oxalate process.

disappears. Oxalic acid at $\sim 1 \mathrm{M}$ concentration is then slowly added over about a $30 \mathrm{~min}$ period, with the solution at $50-60^{\circ} \mathrm{C}$, to obtain the $\mathrm{Pu}$ oxalate precipitate, i.e., $\mathrm{Pu}\left(\mathrm{C}_{2} \mathrm{O}_{4}\right)_{2} 6 \mathrm{H}_{2} \mathrm{O}$. Sufficient oxalic acid is added to give a final concentration of 0.05 to $0.15 \mathrm{M} \mathrm{H}_{2} \mathrm{C}_{2} \mathrm{O}_{4}$ after precipitation is complete. In the second procedure, hydrogen peroxide and $\sim 1 \mathrm{M}$ oxalic acid are added simultaneously and slowly to the solution from the dilution step with the temperature in the 50 $60^{\circ} \mathrm{C}$ range. Sufficient oxalic acid is added to give a final concentration 0.05 to $0.15 \mathrm{M} \mathrm{H}_{2} \mathrm{C}_{2} \mathrm{O}_{4}$. After completing the addition of oxalic acid two additional procedures are described for improving the completeness of the precipitation and the quality of the precipitate. One procedure is to digest the final solution for 1 hour at $50-60^{\circ} \mathrm{C}$, and the other procedure is to chill the solution to less than 10 ${ }^{\circ} \mathrm{C}$ for $20 \mathrm{~min}$.

The next step after precipitation is a wash and decantation step. The precipitate is allowed to settle out and the supernatent liquid is poured off. A wash solution containing $0.05 \mathrm{M} \mathrm{H}_{2} \mathrm{C}_{2} \mathrm{O}_{4}$ and $2 \mathrm{~N} \mathrm{HNO}_{3}$ is then used to wash the precipitate and the precipitate is allowed to settle out again. The wash solution is then poured off. This wash and decant process is repeated several more times to rinse the precipitate of impurities.

After the last wash and decant, the wet precipitate is set out to dry in an open container. Then, as the final step, the dry precipitate is calcined in air to convert it to $\mathrm{Pu}$ oxide. The calcination is carried out in air to avoid carbon retention in the product oxide. 


\section{Experimental Equipment}

Handling of solutions containing ${ }^{238} \mathrm{Pu}$ is currently limited to a glovebox (in Bldg 332, Rm 1006) that has been set up for preparing specimens for induction coupled plasma mass spectrometry (ICPMS). Solutions can be heated in opaque Teflon heater tubes $11 / 8$ " ID by $8^{\prime \prime}$ high using a microwave heater (hot plate heaters are not currently permitted in this glovebox). The heating volume is limited to a maximum of $65 \mathrm{ml}$ of solution when heating with the microwave heater. The heater tube expands to $13 / 4^{\prime \prime}$ ID by $33 / 8^{\prime \prime}$ high above the $8^{\prime \prime}$ zone to provide an air-cooled reflux zone. A secondary reflux chamber of transparent Teflon is attached to the top of the heater tube and extends the reflux chamber an additional $31 / 2 "$. Because the Teflon is transparent in this secondary reflux chamber, it permits visual observation of the degree of refluxing occurring or when full scale boiling occurs. A scrubber system is attached to the top of the secondary reflux chamber to draw off any acid offgases and scrub them in a $25 \%$ $\mathrm{NaOH}$ solution. This draw to the scrubber system provides a partial vacuum on the heater tube. Solutions can be added to the heater tube (e.g., during a heating) through a small diameter Teflon tube using a peristaltic pump to feed in the solutions. The sample temperature is measured by a temperature indicator located just below the heater tube (thermocouples cannot be placed inside of the microwave field). Unfortunately, an accurate temperature of the sample cannot be obtained in this system because of the remote location of the temperature sensor. The temperature reading is believed to usually read $25^{\circ} \mathrm{C}$ higher than the sample temperature at room temperature, but to be about right at $100^{\circ} \mathrm{C}$ and higher. A chiller tank is available for chilling samples. Handling of dry materials, such as grinding and sieving and also the calcining are carried out in gloveboxes in Bldg 332, $\mathrm{Rm} 1010$. Calcining is carried out in $\mathrm{MgO}$ crucibles placed inside of an open top stainless steel can using a slowly flowing air atmosphere.

\section{Initial Experimentation using Weapons Grade Plutonium Oxide}

Because of the difficulty of working with highly radioactive ${ }^{238} \mathrm{Pu}$, an initial experiment was carried out using weapons grade plutonium oxide in order to establish the operating parameters without wasting any ${ }^{238} \mathrm{Pu}$ material. A sample was made up of a mixture of $4.4 \mathrm{~g} \mathrm{PuO}_{2}$ powder and $0.6 \mathrm{~g} \mathrm{UO}_{2}$ powder (approximate weights). The $\mathrm{PuO}_{2}$ was from weapons grade plutonium of unknown purity and the $\mathrm{UO}_{2}$ was from a natural uranium material from Cameco Corporation and had a purity of $>99.9 \%$. The total weight of the powder mixture using a more accurate balance was found to be $5.204 \mathrm{~g}$. The particle size of the powder mixture was not known but it appeared to be a somewhat coarse material, perhaps $200 \mu \mathrm{m}$ and less in particle size. 


\section{Dissolving Step for $\mathrm{PuO}_{2} / \mathrm{UO}_{2}$ Mixture:}

A series of heatings were first carried out in $\mathrm{HNO}_{3} / \mathrm{HF}$ solutions to establish the conditions needed to dissolve the $\mathrm{PuO}_{2} / \mathrm{UO}_{2}$ powder mixture. For the first heating, $19.5 \mathrm{ml}$ of $10 \mathrm{~N} \mathrm{HNO}_{3}$ and $0.5 \mathrm{ml}$ of $2 \mathrm{~N} \mathrm{HF}$ were added to the $\mathrm{PuO}_{2} / \mathrm{UO}_{2}$ sample in a Teflon heater tube and heated by the microwave heater at $64^{\circ} \mathrm{C}$ (true temperature about $50^{\circ} \mathrm{C}$ ) for $75 \mathrm{~min}$. Visual examination showed no color in the solution, indicating no significant amount of $\mathrm{PuO}_{2}$ had dissolved. The sample was then heated at $85^{\circ} \mathrm{C}$ for one hour. At this point, some green color became apparent in the solution. The solution was reheated at $90^{\circ} \mathrm{C}$ for one hour. The solution had turned dark green and some droplets of condensate were

present on the side walls. A large amount of solid sample remained at the bottom of the container.

Since some condensate had been found on the side walls of the heater tube, $5 \mathrm{ml}$ of $15.7 \mathrm{~N} \mathrm{HNO}_{3}$ was added to the solution, and heating continued for 2 hours at $95{ }^{\circ} \mathrm{C}$ followed by 1 hour at $100^{\circ} \mathrm{C}$. Another $5 \mathrm{ml}$ of $15.7 \mathrm{~N} \mathrm{HNO}_{3}$ was added and the solution was heated for 1 hour at $100^{\circ} \mathrm{C}$, followed by heating for 2 hours at $105^{\circ} \mathrm{C}$. In this succession of heatings with increasing temperatures the solution kept getting darker in color. After the last heating the solution was so dark that it was not possible to see through the solution and detect any solid remaining in the bottom of the container. It was assumed at this point that the sample had completely dissolved. The solution was therefore poured out of the heater tube. Whereupon, it was found that a large amount of solid sample remained. In retrospect, it appears that the dissolved portion represented only about $20 \%$ of the sample. It was decided to proceed with oxalate precipitation on the dissolved portion and return later to complete the dissolving of the balance of the sample.

\section{Precipitation of Pu Oxalate:}

The dissolved portion of the sample was passed through a \#40 Whatman filter paper to separate out any carryover of undissolved sample (only a trace amount was present). Approximately $28 \mathrm{ml}$ of solution passed through the paper. Half of the solution, or $14 \mathrm{ml}$, was placed in a heater tube and heated to an indicated temperature of $60^{\circ} \mathrm{C}$ and held at that temperature. The peristaltic pump was then used to slowly add (over a 30 min period) $26.5 \mathrm{ml}$ of a precipitating solution. The $26.5 \mathrm{ml}$ of precipitating solution was taken from a 232 $\mathrm{ml}$ batch prepared by mixing $212 \mathrm{ml}$ of $0.8 \mathrm{M} \mathrm{H}_{2} \mathrm{C}_{2} \mathrm{O}_{2}$ with $20.0 \mathrm{ml}$ of $30 \% \mathrm{H}_{2} \mathrm{O}_{2}$. Thus, the $26.5 \mathrm{ml}$ consisted of a mixture of $24.2 \mathrm{ml}$ of $0.8 \mathrm{M} \mathrm{H}_{2} \mathrm{C}_{2} \mathrm{O}_{4}$ and $2.3 \mathrm{ml}$ of $30 \% \mathrm{H}_{2} \mathrm{O}_{2}$. The sample was visually examined after the precipitating solution had been added and found to be a cloudy mustard yellow color. The sample was allowed to digest in the heater for an hour at $60^{\circ} \mathrm{C}$. It was then placed in the chiller at $\sim 12{ }^{\circ} \mathrm{C}$ overnight. The solution and precipitate were transferred to a wide-mouth glass jar (500 ml capacity) using $38.5 \mathrm{ml}$ of rinse solution $(0.05 \mathrm{M}$ $\mathrm{H}_{2} \mathrm{C}_{2} \mathrm{O}_{4}$ in $2 \mathrm{~N} \mathrm{HNO}_{3}$ ) to aid in the transfer out of the heater tube. The precipitate 
was allowed to settle out for $10 \mathrm{~min}$ and then the solution was decanted off. Another $38.5 \mathrm{ml}$ of rinse solution was added and swirled to wash the precipitate and then allowed $10 \mathrm{~min}$ for the precipitate to settle. The solution was decanted again, but unfortunately about $15 \%$ of the precipitate spilled out during the decanting. Rinse solution, $33 \mathrm{ml}$, was again added and swirled to wash the precipitate. After $10 \mathrm{~min}$ the solution was decanted off and the precipitate was set out in the open wide-mouth glass jar to dry overnight. When dry (oxalate precipitate had a mustard brown color), the Pu oxalate sample weight was measured as $0.6982 \mathrm{~g}$. Based upon the literature the $\mathrm{Pu}$ oxalate was assumed to be hydrated and to have the composition $\mathrm{Pu}\left(\mathrm{C}_{2} \mathrm{O}_{4}\right)_{2} \cdot 6 \mathrm{H}_{2} \mathrm{O}$. Calcining in air at $700{ }^{\circ} \mathrm{C}$ resulted in a sample weight of $0.3433 \mathrm{~g}$. This compares with an expected weight of $0.3409 \mathrm{~g}$ based upon the conversion of $\mathrm{Pu}\left(\mathrm{C}_{2} \mathrm{O}_{4}\right)_{2} \cdot 6 \mathrm{H}_{2} \mathrm{O}$ to $\mathrm{PuO}_{2}$ by calcination. Analysis of a small sample of the $\mathrm{PuO}_{2}$ by ICPMS gave a $\mathrm{U}$ content of $0.39 \mathrm{wt} \%$, which gives a factor of 31 reduction in $U$ content if the portion of the sample that had been dissolved and converted to oxalate, was representative of the proportionate $U$ content of the entire sample.

Examination of the solutions removed by decantation showed that not all of the precipitate had settled out by allowing only $10 \mathrm{~min}$ for settling of the precipitate. A settling time of 1 hour may be a more optimum time. It was also learned that pouring off of the solution by decantation could result in some loss of the precipitate. A better approach would be to remove the solution using a pipette using care to not agitate the precipitate.

\section{Continuation of Dissolving $\mathrm{PuO}_{2} / \mathrm{UO}_{2}$ Mixture:}

The experiment returned to determining the conditions needed to complete the dissolving of the remainder of the sample. All of the undissolved $\mathrm{PuO}_{2} / \mathrm{UO}_{2}$ was placed in a Teflon heater tube and $18 \mathrm{ml}$ of $15.7 \mathrm{~N} \mathrm{HNO}$ and 1.0 $\mathrm{ml}$ of $2 \mathrm{~N} \mathrm{HF}$ were added. The solution was heated for 1 hour at $105^{\circ} \mathrm{C}$ and then examined. The solution had turned a green color indicating some dissolution. The solution was heated for 2 more hours at $105^{\circ} \mathrm{C}$. It was found to be a much darker green and the liquid level was still intact. The solution was reheated to $110^{\circ} \mathrm{C}$ for 1 hour, some condensed droplets were apparent on the walls above the heater tube and an estimated $20 \%$ of the sample remained undissolved. Solution was reheated at $110^{\circ} \mathrm{C}$ for another hour, solid sample still remained. It was reheated at $115^{\circ} \mathrm{C}$ for one hour, some solid sample remained. It was then heated at $120^{\circ} \mathrm{C}$ for 1 hour, still not all dissolved. Because of loss of liquid volume, $10 \mathrm{ml}$ of $15.7 \mathrm{~N} \mathrm{HNO}_{3}$ and $1.0 \mathrm{ml}$ of $2 \mathrm{~N} \mathrm{HF}$ were now added and the solution was heated to $125^{\circ} \mathrm{C}$. After 2 minutes of heating the solution went into a rapid boil. The temperature was dropped to $120^{\circ} \mathrm{C}$ and held for 1 hour. When cool, the solution was poured out and saved. About $10 \%$ of the undissolved solid still remained.

An additional $25 \mathrm{ml}$ of $15.7 \mathrm{~N} \mathrm{HNO}_{3}$ and $1.5 \mathrm{ml}$ of $2 \mathrm{~N} \mathrm{HF}$ were added to the remaining solid in the heater tube, and the sample was heated for 1 hour at 120 
${ }^{\circ} \mathrm{C}$. Examination after the heating showed that a small amount of solid still remained. All but about $1.5 \mathrm{ml}$ of the solution was poured off and saved. Fresh solution, $10 \mathrm{ml} 15.7 \mathrm{~N} \mathrm{HNO}_{3}$ and $0.2 \mathrm{ml}$ of $2 \mathrm{~N} \mathrm{HF}$ were added to the heater tube, and heating begun at $120^{\circ} \mathrm{C}$. Heating was shut down after $27 \mathrm{~min}$ because the temperature readings were erratic, ranging from 117 to $145^{\circ} \mathrm{C}$. Examination of the sample showed that boiling had occurred and only about $1.5 \mathrm{ml}$ of solution remained. It appeared that boiling had occurred because of the small volume (10 $\mathrm{ml}$ ) of dissolving solution used. Additional amounts of $20 \mathrm{ml}$ of $15.7 \mathrm{~N} \mathrm{HNO}_{3}$ and $1.0 \mathrm{ml}$ of $2 \mathrm{~N} \mathrm{HF}$ were now added to the vessel and the sample was reheated for 2 hours at $120^{\circ} \mathrm{C}$. Examination showed that very little of the solution had been lost during the heating. The solution was then poured off and added to the previous dissolving solutions. Only a slight trace of solid material remained in the vessel. Further dissolving was abandoned considering the small amount of solid material left.

\section{Continuation of $\mathrm{Pu}$ Oxalate Precipitations:}

The accumulated dissolving solutions had a volume of $78 \mathrm{ml}, 14 \mathrm{ml}$ had remained from the first dissolving and about $20-22 \mathrm{ml}$ each came from the three subsequent dissolvings. In order to proceed with oxalate precipitations, the dissolving solution was diluted with $138 \mathrm{ml}$ of water to give a diluted volume of $216 \mathrm{ml}$. It was planned to split this $216 \mathrm{ml}$ into 5 batches of $43 \mathrm{ml}$ each to do the oxalate precipitations.

The first $43 \mathrm{ml}$ batch of diluted dissolving solution was heated in a Teflon heater tube to $65^{\circ} \mathrm{C}$ (true temperature is estimated to be $50-55^{\circ} \mathrm{C}$ ), and $16 \mathrm{ml}$ of oxalate precipitating solution (taken from the original mixture of $212 \mathrm{ml}$ of $0.8 \mathrm{M}$ $\mathrm{H}_{2} \mathrm{C}_{2} \mathrm{O}_{4}$ with $20 \mathrm{ml}$ of $30 \% \mathrm{H}_{2} \mathrm{O}_{2}$ solution) was added over a 20 min period. The heater was momentarily stopped every 5 min during addition of the precipitating solution and the sample was shaken to provide stirring. After completion of addition of the precipitating solution, the sample was heated at $65^{\circ} \mathrm{C}$ for an additional hour to improve the quality of the precipitate. Examination of the sample showed that a very small amount of precipitate had formed and a dark color remained in the solution. It was decided to pursue additional precipitation. Most of the supernate was removed with the precipitate remaining in the heater tube, and $43 \mathrm{ml}$ of the supernate was then returned to the heater tube. One $\mathrm{ml}$ of $30 \% \mathrm{H}_{2} \mathrm{O}_{2}$ was added to the heater tube. The sample was now heated to $62{ }^{\circ} \mathrm{C}$ and $16 \mathrm{ml}$ of precipitating solution added over a $16 \mathrm{~min}$ period with shaking of the heater tube every $5 \mathrm{~min}$. The sample was then held at $62{ }^{\circ} \mathrm{C}$ for 1 hour.

Examination of the sample after the heating showed that the amount of precipitate had increased slighty. Results of this precipitation were disappointingly low.

It was decided to run a second batch using somewhat different conditions. Only $30 \mathrm{ml}$ of the diluted dissolved solution was taken instead of $43 \mathrm{ml}$. To this were added $14 \mathrm{ml}$ of water and $1 \mathrm{ml}$ of $30 \% \mathrm{H}_{2} \mathrm{O}_{2}$ solution to give a total volume. 
of $45 \mathrm{ml}$ of solution. The sample was heated to $60^{\circ} \mathrm{C}$ and $20 \mathrm{ml}$ of the previously prepared $\mathrm{H}_{2} \mathrm{C}_{2} \mathrm{O}_{4} / \mathrm{H}_{2} \mathrm{O}_{2}$ solution was added over a $41 \mathrm{~min}$ period with shaking of the heater tube every $5 \mathrm{~min}$. The heater was held an additional $36 \mathrm{~min}$ at $60^{\circ} \mathrm{C}$ and then turned off. Examination of the sample showed no precipitate formation. At this point there was a suspicion that the previously prepared solution of $\mathrm{H}_{2} \mathrm{C}_{2} \mathrm{O}_{4} / \mathrm{H}_{2} \mathrm{O}_{2}$ had deteriorated over a period of 9 days from preparation to use. It was not clear whether the deterioration was in the $\mathrm{H}_{2} \mathrm{C}_{2} \mathrm{O}_{4}$ or the $\mathrm{H}_{2} \mathrm{O}_{2}$ content, or in both.

A third batch was run to test the precipitation with a fresh mixture of $\mathrm{H}_{2} \mathrm{C}_{2} \mathrm{O}_{4}$ and $\mathrm{H}_{2} \mathrm{O}_{2}$. A $38 \mathrm{ml}$ sample of the diluted dissolved solution was loaded into the heater tube and $13 \mathrm{ml}$ of water was added. The sample was heated to $70^{\circ} \mathrm{C}$ (true temperature about $60^{\circ} \mathrm{C}$ ) and a freshly prepared mixture of $13 \mathrm{ml}$ of $0.8 \mathrm{M} \mathrm{H}_{2} \mathrm{C}_{2} \mathrm{O}_{4}$ and $0.9 \mathrm{ml}$ of $30 \% \mathrm{H}_{2} \mathrm{O}_{2}$ was added to the sample over a $32 \mathrm{~min}$ period with shaking of the heater tube every $5 \mathrm{~min}$. The heater was then held an additional $42 \mathrm{~min}$ at $70^{\circ} \mathrm{C}$. Examination of the sample showed that a large amount of precipitate had formed and the solution was now a straw color indicating that $\mathrm{Pu}$ was depleted from the solution. A fourth batch was run repeating the conditions of the third batch and gave the same results. This verified that a fresh mixture of $\mathrm{H}_{2} \mathrm{C}_{2} \mathrm{O}_{4}$ and $\mathrm{H}_{2} \mathrm{O}_{2}$ needs to be prepared for each precipitation run.

\section{Discussion of Weapons Grade Plutonium Experiments}

We learned from the weapons grade plutonium experiments that the dissolution of the $\mathrm{PuO}_{2} / \mathrm{UO}_{2}$ material is a difficult process. It is important to hold the temperature close to the boiling point but sufficiently below the boiling point (e.g., about $10^{\circ} \mathrm{C}$ lower) that loss of solution by vaporization is minimal. Because of the difficulty of dissolution, it would be helpful to work with a finer particle size of the $\mathrm{PuO}_{2} / \mathrm{UO}_{2}$ material than was used here. It should be helpful to grind the material to -325 mesh $(<42 \mu \mathrm{m})$ in a mortar and pestle. A critical issue was the age of the $\mathrm{H}_{2} \mathrm{C}_{2} \mathrm{O}_{4} / \mathrm{H}_{2} \mathrm{O}_{2}$ precipitating solution. $\mathrm{H}_{2} \mathrm{C}_{2} \mathrm{O}_{4} / \mathrm{H}_{2} \mathrm{O}_{2}$ mixed solutions that are held for nine days deteriorate and are no longer adequate for precipitation. To be on the safe side, we need to prepare freshly mixed solutions of $\mathrm{H}_{2} \mathrm{C}_{2} \mathrm{O}_{4} / \mathrm{H}_{2} \mathrm{O}_{2}$ just prior to use to assure that they function properly. We learned that because of the fineness of the oxalate precipitate, it requires at least an hour to settle out before decanting. Also, using a pipette to remove the supernate is a better-controlled procedure than pouring it off by decantation.

The weight change on calcination of the $\mathrm{Pu}$ oxalate formed in this study confirmed that the formula for the $\mathrm{Pu}$ oxalate was $\mathrm{Pu}\left(\mathrm{C}_{2} \mathrm{O}_{4}\right)_{2} \cdot 6 \mathrm{H}_{2} \mathrm{O}$. For the one. analysis for uranium in the product, the uranium content was found to be $0.39 \%$, which is a reduction of a factor of 31 compared to the original material. However, this analysis is not a definitive number because it represents dissolution of only about $20 \%$ of the original material. The solution rate of $\mathrm{UO}_{2}$ is known to exceed that of $\mathrm{PuO}_{2}{ }^{4}$ hence the dissolved portion that was processed had a higher 
uranium content than the original sample, and the reduction factor for uranium is therefore greater than 31 .

\section{Experiments on ${ }^{238} \mathrm{Pu}$-enriched $\mathrm{PuO}_{2}$}

Our goal was to produce $15 \mathrm{~g}$ of ${ }^{238} \mathrm{Pu}$ in the form of ${ }^{238} \mathrm{PuO}_{2}$ that was purified of ${ }^{234} \mathrm{U}$. The material available for processing was $62 \mathrm{~g}$ of a material designated as CAP 5 that was obtained from the Los Alamos National Laboratory in 1989 and was in the form of sintered oxide discs 3/4" in dia. Calorimetric and gamma-ray analyses on May 3, 2001, gave a ${ }^{238} \mathrm{Pu}$ content of $36.656 \mathrm{gg}{ }^{239} \mathrm{Pu}$ $8.129 \mathrm{~g},{ }^{240} \mathrm{Pu} 1.277 \mathrm{~g},{ }^{241} \mathrm{Pu} 0.115 \mathrm{~g},{ }^{242} \mathrm{Pu} 0.093 \mathrm{~g}$, and ${ }^{241} \mathrm{Am} 0.195 \mathrm{~g}$. As the dioxides, these constituents would give a total weight of $52.712 \mathrm{~g}$. By difference, the remaining weight of $62-52.712=9.288 \mathrm{~g}$, is estimated as the weight of ${ }^{234} \mathrm{UO}_{2}$, or a weight of $8.171 \mathrm{~g}$ as the weight of ${ }^{234} \mathrm{U}$.

In preparation for dissolving, discs of the CAP $5{ }^{238} \mathrm{PuO}_{2}$ material were broken up and ground in a porcelain mortar and pestle to pass a 325 mesh screen. Eight batches labeled CAP-5-A through CAP-5-H and weighing $\sim 5 \mathrm{~g}$ each were prepared.

Dissolving of ${ }^{238} \mathrm{PuO}_{2}$ :

CAP-5-A (weight $4.32 \mathrm{~g}$ ) was loaded into a Teflon heater tube, $25 \mathrm{ml}$ $15.7 \mathrm{~N} \mathrm{HNO}_{3}$ and $1.0 \mathrm{ml} 2 \mathrm{~N} \mathrm{HF}$ were added, and the sample was heated at 110 ${ }^{\circ} \mathrm{C}$ with the microwave heater for $91 / 4$ hours. Examination of the sample showed that only a small residue of solid remained. It was decided that the solution would be poured off, retaining the solid residue in the heater tube so it would be combined with the next sample to be dissolved. The solutions from a number of batches would be combined before proceeding with the processing steps. The solution from CAP-5-A was therefore stored in a $125 \mathrm{ml}$ polyethylene bottle.

CAP-5-B (weight $4.80 \mathrm{~g}$ ) was added to the heater tube with $25 \mathrm{ml} 15.7 \mathrm{~N}$ $\mathrm{HNO}_{3}$ and $1.0 \mathrm{ml} 2 \mathrm{~N} \mathrm{HF}$ and the sample was heated at $110^{\circ} \mathrm{C}$ for 7 hours. About $10 \%$ of the solid remained undissolved. The solution was added to the solution from CAP-5-A in the polyethylene bottle. A few hours after the addition it was found that the CAP-5-A and CAP-5-B solutions had flowed out of cracks (formed by radiation damage) in the polyethylene bottle into a containment tray. The solutions were absorbed onto diaper paper and stored in wide mouth glass bottles for future recovery of the material by calcination. It was decided to use glass containers to store ${ }^{238} \mathrm{Pu}$ containing solutions because the radiation damage of polyethylene by ${ }^{238} \mathrm{Pu}$ is too severe for storing ${ }^{238} \mathrm{Pu}$ solutions.

Five batches, CAP-5-C through CAP-5-G, weighing a total of $25.32 \mathrm{~g}$ together with $\sim 0.5 \mathrm{~g}$ that was left over from CAP-5-B above, were next dissolved 
and the solutions stored in a $500 \mathrm{ml}$ wide mouth glass jar. Each batch was dissolved in $25 \mathrm{ml} 15.7 \mathrm{~N} \mathrm{HNO}_{3}$ plus $1.0 \mathrm{ml}$ of $2 \mathrm{~N} \mathrm{HF}$ by heating for 12 hours at $110^{\circ} \mathrm{C}$. The final batch was heated for 13.6 hours to assure that a negligible amount of residue remained behind in the heater tube.

Precipitation of ${ }^{238} \mathrm{Pu}$ Oxalate:

After dissolving batches CAP-5-C through CAP-5-G, the combined solution was filtered through a glass fiber filter (more durable than paper filters for the acid solutions) to remove traces of solid residue that had been carried over when removing the solutions from the heater tube. To prepare the solution for oxalate precipitation, the solution was diluted by addition of $320 \mathrm{ml}$ of water. Assuming each dissolving batch was $26 \mathrm{ml}$, the total volume of solution should now be (26)(5) $+320=450 \mathrm{ml}$. This was planned to be split up into 12 batches of $\sim 37 \mathrm{ml}$ each to do the oxalate precipitations.

The oxalate precipitations were carried out as follows. A $37 \mathrm{ml}$ batch of diluted solution was placed in the Teflon heater tube and heated to $70^{\circ} \mathrm{C}$ (true temperature $\sim 60^{\circ} \mathrm{C}$ ). The precipitating solution, a freshly mixed batch of $29 \mathrm{ml}$ $0.8 \mathrm{MH}_{2} \mathrm{C}_{2} \mathrm{O}_{4}$ plus $2 \mathrm{ml} \mathrm{H}_{2} \mathrm{O}_{2}$, was added over a 36 min period with shaking of the heater tube every 5 min during addition. The sample tube was heated at $70{ }^{\circ} \mathrm{C}$ for another $30 \mathrm{~min}$ after the precipitating solution was added, and then the heater tube was transferred to the chiller for at least an hour. The solution and precipitate were then transferred to a wide mouth glass jar to allow the precipitate to settle. The precipitate was observed to be a dark brown color instead of the straw yellow color that had been observed with the weapons grade plutonium. With time (a few days) the precipitate changed to the straw yellow color, but now the supernate darkened in color (purplish brown) indicating that Pu was in solution.

As the end of the oxalate precipitations was approached, it became clear that instead of the planned 12 batches there were only 10 batches, and the last batch was only $25 \mathrm{ml}$ instead of $37 \mathrm{ml}$. Thus, the total volume of the diluted solution was about $360 \mathrm{ml}$ instead of $450 \mathrm{ml}$. It would appear that the volume of the dissolved solutions had been $\sim 40 \mathrm{ml}$ instead of the $130 \mathrm{ml}$ we had assumed. This means that a large fraction of the nitric acid had been boiled down during the dissolving step, and hence the nitric acid concentration was much lower than planned at the end of the precipitations, i.e., the nitric acid concentration was 0.9 $\mathrm{N}$ instead of $2.5 \mathrm{~N}$. The literature does not recommend $\mathrm{Pu}$ oxalate precipitations at less than $1.5 \mathrm{~N} \mathrm{HNO}_{3}$. The lower acidities give precipitates that are too fine for rapid settling and give more coprecipitation of impurities. ${ }^{1}$

Considering that the color of the Pu oxalate looked right after it had sat for a few days, we separated away the supernate with a pipette. The supernate was saved for later processing to recover more Pu oxalate. The wet precipitate of $\mathrm{Pu}$ oxalate was allowed to dry overnight, then weighed, and found to be $2.46 \mathrm{~g}$. The oxalate sample was sent to be calcined. This is a very low yield of oxalate 
considering that $25.82 \mathrm{~g}$ of ${ }^{238} \mathrm{PuO}_{2}$ had been processed. Most of the plutonium must still be in the supernate.

\section{Reprocess the Supernate:}

The following procedure was used in reprocessing the supernate. The supernate volume was $670 \mathrm{ml}$. Batch sizes ranging from 35 to $80 \mathrm{ml}$ were taken out of this for processing. For a typical processing, a $70 \mathrm{ml}$ batch was placed in a teflon heater tube, $7 \mathrm{ml}$ of $15.7 \mathrm{~N} \mathrm{HNO}_{3}$ and $10 \mathrm{ml}$ of $30 \% \mathrm{H}_{2} \mathrm{O}_{2}$ were added and the batch was heated to $80^{\circ} \mathrm{C}$ (true temperature about $70^{\circ} \mathrm{C}$ ) for $15 \mathrm{~min}$. The amount of nitric acid added was calculated to result in a $2.5 \mathrm{~N}$ nitric acid concentration at the end of the precipitation. A large excess of $\mathrm{H}_{2} \mathrm{O}_{2}$ was added to assure conversion of the $\mathrm{Pu}$ to the +4 state. The heater was then turned off and the sample immediately transferred to a wide mouth glass jar. The temperature of the solution was monitored with a thermometer and when it reached $\sim 60^{\circ} \mathrm{C}$, precipitating solution (a freshly made mixture of $29 \mathrm{ml} 0.8 \mathrm{M}$ $\mathrm{H}_{2} \mathrm{C}_{2} \mathrm{O}_{4}$ with $2 \mathrm{ml}$ of $30 \% \mathrm{H}_{2} \mathrm{O}_{2}$ ) was slowly added over a $15 \mathrm{~min}$ period while swirling the solution in the jar. Precipitation could be observed over about the first $10 \mathrm{~min}$ of addition, then no further precipitation was apparent. The precipitate was a light tan color and the solution was cloudy and had a straw yellow color. After adding the precipitation solution, the precipitate and solution were transferred to a $500 \mathrm{ml}$ wide mouth glass jar. Upon completion of all of the precipitations, two $500 \mathrm{ml}$ wide mouth glass jars were nearly filled by the precipitate and supernate products. As the material sat in the jars, gas bubbles could be seen emanating from the surface of the precipitate at a rate of one or two bubbles per second for each jar. This was believed to be a result of radiolytic decomposition of oxalic acid. After the last addition to the jars, the precipitate was allowed an hour to settle out and then the supernates were removed with a pipette. The precipitates were combined and washed three times with $75 \mathrm{ml}$ of wash solutions of $0.05 \mathrm{M} \mathrm{H}_{2} \mathrm{C}_{2} \mathrm{O}_{4}$ and $2 \mathrm{~N} \mathrm{HNO}_{3}$. The solutions were removed with a pipette once the precipitate settled out after each wash. The precipitate was then allowed to dry overnight, weighed $(16.56 \mathrm{~g})$, and sent out to be calcined.

The two oxalate samples $(2.46+16.56=19.02 \mathrm{~g})$ obtained from CAP-5-C through CAP-5-G were calcined at $1000^{\circ} \mathrm{C}$ in slowly flowing air for one hour to form $\mathrm{PuO}_{2}$. Examination of the sample after the run showed that flakes of metal oxide from the stainless steel secondary containment vessel had fallen on top of the sample. The flakes were found to be attracted by a magnet and were easily removed with the magnet. The sample was then weighed and found to be 17.5 g. Of this, the weight of ${ }^{238} \mathrm{Pu}$ was calculated to be $12.2 \mathrm{~g}$. Another $2.8 \mathrm{~g}$ of ${ }^{238} \mathrm{Pu}$ were still needed. 


\section{Process One More Sample:}

One more sample, CAP-5-H $(6.09 \mathrm{~g})$, was processed to obtain the additional ${ }^{238} \mathrm{Pu}$ that was needed. The sample was loaded into a Teflon heater tube, $35 \mathrm{ml}$ of $15.7 \mathrm{~N} \mathrm{HNO}_{3}$ and $2 \mathrm{ml}$ of $2 \mathrm{~N} \mathrm{HF}$ were added, and the sample was heated at $110^{\circ} \mathrm{C}$ for 13.2 hours. The resulting solution was diluted with water to a volume of $125 \mathrm{ml}$. This would be split into 3 batches of $42 \mathrm{ml}$ each for the oxalate precipitations. To each $42 \mathrm{ml}$ batch, $5 \mathrm{ml}$ of $30 \% \mathrm{H}_{2} \mathrm{O}_{2}$ was added and the solution was heated to $80^{\circ} \mathrm{C}$ for $10 \mathrm{~min}$. The solution was then transferred to a wide mouth glass jar, and when below $60^{\circ} \mathrm{C}$, a freshly prepared mixture of 25 $\mathrm{ml}$ of $0.8 \mathrm{M} \mathrm{C}_{2} \mathrm{H}_{2} \mathrm{O}_{4}$ and $2 \mathrm{ml}$ of $30 \% \mathrm{H}_{2} \mathrm{O}_{2}$ was slowly added while swirling the solution in the jar. As before, the solutions and precipitates were collected in a wide mouth glass jar where the precipitate settled out, the supernate was removed, the precipitate was washed three times, and then allowed to dry overnight. The Pu oxalate precipitate weighed $4.46 \mathrm{~g}$. It was calcined as before to give a weight of $\mathrm{PuO}_{2}$ of $3.7 \mathrm{~g}$, which when added to the previously calcined oxide gave a total weight of $21.2 \mathrm{~g}$. The calculated ${ }^{238} \mathrm{Pu}$ content of this material is $14.8 \mathrm{~g}$. Mass spectroscopic analysis of a small sample gave a ${ }^{234} \mathrm{U}$ content of 0.0254 wt $\%$.

\section{ICPMS Analyses:}

ICPMS analyses were made on mass peaks 234-242 for the dissolved ${ }^{238} \mathrm{PuO}_{2}$ accumulated from CAP-5-C through CAP-5-G. Analyses were also made on supernates from the first oxalate precipitation and from the second oxalate precipitation. These analyses are summarized in Table 1 along with the May 3, 2001, calorimetric and gamma-ray analyses. The ICPMS analyses are

Table 1. Mass analyses for masses 234 through 242 taken at various $\mathrm{Pu}$ oxalate processing stages for samples CAP-5-C through CAP-5-G.

Percent abundance of mass number

\begin{tabular}{lcccccc} 
& 234 & 238 & 239 & 240 & 241 & 242 \\
\cline { 2 - 7 } Analysis of original solid & 14.96 & 67.09 & 14.88 & 2.34 & 0.57 & 0.17 \\
Analysis of dissolved solid & 15.0 & 65.5 & 16.2 & 2.5 & 0.7 & 0.2 \\
Analysis of first supernate & 22.6 & 59.6 & 14.8 & 2.3 & 0.5 & 0.2 \\
Analysis of second supernate & 84.2 & 9.9 & 5.0 & 0.6 & 0.3 & 0.0 \\
\hline
\end{tabular}

only semi-quantitative but show approximate agreement of the dissolved solid data with the May 3, 2001, calorimetric and gamma-ray analyses. The supernate from the first oxalate precipitation shows only a minor increase in the ${ }^{234} \mathrm{U}$ in 
solution and a minor decrease in the Pu in solution, thus indicating that only a small part of the Pu precipitated as oxalate. This is consistent with our experimental observation. The supernate from the second oxalate precipitation shows a major increase in ${ }^{234} \mathrm{U}$ in solution and a major decrease in the Pu in solution, again in agreement with the experimental observation. However, a small amount of Pu still remains in the second supernate.

\section{Process Yield:}

An estimate can be made of the yield of ${ }^{238} \mathrm{Pu}$ by this process. We processed $31.9 \mathrm{~g}$ of the CAP 5 material which contained $(31.9 / 62)(36.656)=$ $18.86 \mathrm{~g}$ of ${ }^{238} \mathrm{Pu}$. We produced $14.8 \mathrm{~g}$ of ${ }^{238} \mathrm{Pu}$ in the product. The process yield is therefore $(14.8 / 18.86)(100)=78.5 \%$. The literature ${ }^{4}$ indicates that an $\sim 99 \%$ yield is possible. We examined the supernate from the CAP-5-H sample 22 days after separation from the Pu oxalate precipitate to see it there was any evidence for retention of $\mathrm{Pu}$. It showed that a small amount of $\mathrm{Pu}$ oxalate precipitate (estimate as a few tenths of a gram) had settled out, but also that the solution had turned a dark green indicating Pu was in solution. So it appears that a very fine precipitate continued to settle out, but also that radiolysis effects on the Pu oxalate precipitate and of the oxalic acid had put some Pu back into solution. Supernate removed from the weapons grade Pu experiments (now over two months old) was also examined. It also showed that a small amount of precipitate had settled out, but the solution was clear and colorless.

\section{Discussion of ${ }^{238} \mathrm{Pu}$-enriched $\mathrm{PuO}_{2}$ Experiments}

It was found that $5 \mathrm{~g}$ samples of -325 mesh ${ }^{238} \mathrm{Pu}$-enriched $\mathrm{PuO}_{2}$ materials could be dissolved in a mixture of $25 \mathrm{ml} 15.7 \mathrm{~N} \mathrm{HNO}_{3}$ and $1.0 \mathrm{ml} 2 \mathrm{~N} \mathrm{HF}$ in 12 hours at $110^{\circ} \mathrm{C}$. Once dissolved, the solutions could not be stored in polyethylene because of severe radiation damage to the container. Glass provided a suitable storage container. It is important to track the nitric acid concentration during the precipitation step. An optimum nitric acid concentration of $2.5-3.5 \mathrm{~N}$ is needed at the end of the precipitation to assure good crystallinity in the precipitates. It was found that as the precipitate sits in the supernate, radiolysis effects take place that result in Pu going back into solution. The nature of this radiolysis is not understood, but is believed to be a combination of breakdown of both the Pu oxalate and the oxalic acid.

Radiolysis had a significant effect on the product oxalate. Part of the effect is thermal with temperatures of about $100-140^{\circ} \mathrm{C}$ expected from self heating. At these temperatures, the Pu oxalate would lose its waters of hydration and become $\mathrm{Pu}\left(\mathrm{C}_{2} \mathrm{O}_{4}\right)_{2}$. There is also some evidence that $\mathrm{Pu}\left(\mathrm{C}_{2} \mathrm{O}_{4}\right)_{2}$ begins to decompose below $140^{\circ} \mathrm{C} .{ }^{1}$ However, in our case with ${ }^{238} \mathrm{Pu}$ oxalate, the weight of product oxalate $(2.46+16.56+4.46=23.48 \mathrm{~g})$ is only slightly higher than the product oxide $(21.2 \mathrm{~g})$, indicating that the oxalate is nearly completely 
decomposed to oxide. The oxalate weight would have been expected to be $34.54 \mathrm{~g}$ if oxalate decomposition had not occurred.

The ${ }^{234} \mathrm{U}$ content of the purified oxide was analysed as $0.0254 \mathrm{wt} \%$ as compared to a starting value of $13.2 \mathrm{wt} \%$. This gives a reduction factor of 519 for the ${ }^{234} \mathrm{U}$. We would have expected a reduction factor of $\sim 60 .{ }^{1}$ Perhaps the small sample selected for analysis was not representative of the entire material and gave too low a value for the ${ }^{234} \mathrm{U}$.

The process yield for Pu was found to be about $78.5 \%$, which is low compared to the literature. ${ }^{4}$ There may be steps that we can take to try to increase the yield: (1) after precipitation, digest the precipitate and supernate for up to an hour at $60^{\circ} \mathrm{C}$, (2) chill the precipitate and supernate for 20 min below 10 ${ }^{\circ} \mathrm{C}$, and (3) wait longer (perhaps 16 hours) for the precipitate to settle out before removing the supernate. Although these steps may increase the yield they substantially increase processing time and may also increase radiolytic decomposition of the ${ }^{238} \mathrm{Pu}$ oxalate precipitate and of the oxalic acid.

\section{Acknowledgements}

The authors gratefully acknowledge the following: the suggestion of Bartley $\mathrm{B}$. Ebbinghaus to use the $\mathrm{Pu}$ oxalate process for purifying $\mathrm{PuO}_{2}$, the work of Kenneth E. Raschke on calorimetric and gamma-ray analyses of the starting material, and the work of Kenton Moody and Jackie Kenneally on mass spectrometric analysis for ${ }^{234} \mathrm{U}$.

\section{References}

1. J. F. Facer, Jr. and K. M. Harmon, "Precipitation of Plutonium (IV) Oxalate," Hanford Atomic Products Operation Report, HW-31186 (Del.), Mar. 30, 1954, declassified with deletions Dec. 7, 1962.

2. K. M. Harmon and W. H. Reas, "Conversion Chemistry of Plutonium Nitrate," in Progress in Nuclear Energy, Series III, Process Chemistry, Vol. 2, edited by F. R. Bruce, J. M. Fletcher, and H. H. Hyman, Pergamon Press, New York, 1958.

3. Gmelin Handbuch der Anorganischen Chemie, Band 20, Transurane, Teil D1: Chemie in Losung, edited by Gunter Koch, Springer-Verlag, Berlin, 1975.

4. Plutonium Handbook, A Guide to the Technology, Volumes I and II, edited by O. J. Wick, American Nuclear Society, La Grange Park, Illinois, 1980. 